\title{
Correction to: Groundwater geochemical facie: implications of rock-water interaction at the Chamba city (HP), northwest Himalaya, India
}

\author{
Pawan Kumar $^{1}$ - Ambrish Kumar Mahajan ${ }^{1}$ - Anil Kumar ${ }^{2}$ \\ Published online: 27 February 2020 \\ (C) Springer-Verlag GmbH Germany, part of Springer Nature 2020
}

Correction to: Environmental Science and Pollution Research https://doi.org/10.1007/s11356-019-07078-7

The correct presentation of Eq. 10 is shown in this paper. The original article was corrected.

$\mathrm{CAl}-2=\left[\mathrm{Cl}-\left(\mathrm{Na}^{+}+\mathrm{K}^{+}\right)\right] /\left(\mathrm{HCO}_{3}{ }^{-}+\mathrm{CO}_{3}{ }^{2-}+\mathrm{SO}_{4}{ }^{2}-+\mathrm{NO}_{3}{ }^{-}\right)$

The online version of the original article can be found at https://oi.org/ 10.1007/s11356-019-07078-7

\footnotetext{
Pawan Kumar

pawan.evs@gmail.com

1 Department of Environmental Sciences, Central University of Himachal Pradesh, Dharamshala 176215, India

2 Himachal Regional Centre, GB Pant National Institute of Himalayan Environment and Sustainable Development, Kullu, Mohal 175126, India
} 